\title{
Murine leukemia viruses (MuLV) and Xenotropic MuLV-related viruses exhibit inter-tropic complex recombination patterns
}

\author{
Mattia C F Prosperi ${ }^{1 *}$, William M Switzer ${ }^{2}$, Walid Heneine ${ }^{2}$, Marco Salemi ${ }^{1}$ \\ From 15th International Conference on Human Retroviruses: HTLV and Related Viruses \\ Leuven and Gembloux, Belgium. 5-8 June 2011
}

\section{Background}

Murine leukemia viruses (MuLV) are classified into three groups by host tropism correlating with viral receptor sequences present in the surface protein of env. Ecotropic MuLV are found only in mice, xenotropic replicate in non-mouse cells, and polytropic in mouse and non-mouse hosts. Xenotropic MuLV-related viruses (XMRV) and polytropic MuLV have been found in humans and reported in different diseases, including prostate cancer and chronic fatigue syndrome. Classification of MuLV tropism is typically done using small portions of gag/pol, however, this may be complicated by viral recombination.

\section{Methods and results}

Eight eco/poly/xenotropic MulV complete genomes were selected from GenBank, plus an XMRV sequence. The dataset showed strong phylogenetic signal. By tropismgroup analysis using SimPlot software, XMRV was detected as a mosaic recombinant form of all three groups. Using more sensitive analyses, we found evidence of intertropic recombination, especially outside of env. Different procedures for recombination analysis (SimPlot/ TOPALi2), applied to the whole dataset independently from the tropism, inferred discordant break-points.

\section{Conclusions}

Given the evidence of inter-tropic recombination in $\mathrm{MuLV}$, detection and classification of recombination in XMRV using different MuLV tropism prototypes should

\footnotetext{
* Correspondence: m.prosperi@epi.ufl.edu

'Department of Pathology, Immunology and Laboratory Medicine, Emerging Pathogens Institute, College of Medicine, University of Florida, Gainesville, Florida, USA

Full list of author information is available at the end of the article
}

be interpreted with caution. Despite using a small dataset, a strong phylogenetic signal in the alignments and highly resolved phylogenies inferred both by full-length and sliding-window approaches, different recombination programs reported conflicting results. These results suggest that identification of parental strains of the potential recombinants is difficult and that recombination in the highly genetically related MuLV have been occurring for some time.

\section{Author details}

${ }^{1}$ Department of Pathology, Immunology and Laboratory Medicine, Emerging Pathogens Institute, College of Medicine, University of Florida, Gainesville, Florida, USA. ${ }^{2}$ Laboratory Branch, Division of HIV/AIDS Prevention, National Center for HIV/AIDS, Viral Hepatitis, STD, and TB Prevention, Centers for Disease Control and Prevention, Atlanta, GA, 30333, USA.

Published: 6 June 2011

doi:10.1186/1742-4690-8-S1-A235

Cite this article as: Prosperi et al:: Murine leukemia viruses (MuLV) and Xenotropic MuLV-related viruses exhibit inter-tropic complex recombination patterns. Retrovirology 2011 8(Suppl 1):A235.

Submit your next manuscript to BioMed Central and take full advantage of:

- Convenient online submission

- Thorough peer review

- No space constraints or color figure charges

- Immediate publication on acceptance

- Inclusion in PubMed, CAS, Scopus and Google Scholar

- Research which is freely available for redistribution

\section{Biomed Central}

(C) 2011 Prosperi et al; licensee BioMed Central Ltd. This is an open access article distributed under the terms of the Creative Commons Attribution License (http://creativecommons.org/licenses/by/2.0), which permits unrestricted use, distribution, and reproduction in any medium, provided the original work is properly cited. 